\title{
Impact of climate change on the phytoplankton community of the Aglou-Sidi Ifni coastline (Moroccan Atlantic coast)
}

\author{
El mahjoub Gallouli ${ }^{1}$, Hassan Oulad Ali $^{1}$, and Ahmed Aamiri ${ }^{1}$ \\ ${ }^{1}$ Biodiversity and Ecosystem Functioning Team, Ibn Zohr University, Faculty of Sciences, \\ Department of Biology, Agadir, Morocco.
}

\begin{abstract}
The objective of this study is to understand the evolution of the typologies (physicochemical and phytoplankton) in Aglou-Sidi Ifni coastline according to hydrometeorological and climatic hazards. To achieve this objective, monitoring of the phytoplankton community and water physicochemical parameters was conducted at three stations along this coastline and during the winter and fall seasons of two different annual cycles (2014-2016). The first cycle experienced heavy flooding while the second cycle experienced severe drought. This study revealed spatial and temporal variability in phytoplankton composition and the relative abundance of its major groups. Temporal variability may be due to changes in the physicochemical characteristics of water masses as a function of continental inputs and wave intensity, which differ from cycle to cycle and season to another. Whereas the spatial variability would be due to the modification of these physicochemical characteristics from one station to another under the influence of the morphology of the coast in this zone, which curves westwards and carries Cape Aglou at its northern end, thus making the station of Sidi Ifni more exposed to currents than the other two stations which are somewhat sheltered.
\end{abstract}

\section{Introduction}

Phytoplankton is a major component of aquatic ecosystems in general and oceanic ecosystems in particular [1]. It forms the first link in most pelagic chains and thus conditions the richness of the waters and the resource. Phytoplankton production by photosynthesis is under the control of limiting physicochemical factors such as light and nutrients (nitrogen, phosphorus, silica, etc.), whose availability is largely linked to the state of the water column (water mass mixing, exchanges with the continental environment, rainfall, winds, turbidity, temperature) [2]. At the regional scale, these systems are sensitive to climatic forcing through the concomitant action of pressure fields, wind intensity and direction, temperature and precipitation on the variability of physicochemical elements in the water column [3]. The sensitivity of these organisms to changes in environmental factors is high and small fluctuations in these parameters can have pronounced effects on

\footnotetext{
* Corresponding author: melgallouli@yahoo.fr
} 
the structure of marine phytoplankton communities [4], and consequently on the other links in the food webs of marine ecosystems. The Aglou-Sidi Ifni coastline of the Moroccan Atlantic coast is characterized by significant fishery richness and a natural deposit of mussels and is home to one of the three first pilot marine protected areas in Morocco. It is the Massa Marine Protected Area (AMP-Massa). This coastline of the Guelmim-Oued Noun region belongs to the arid bioclimatic stage [5]. The climate of this region is predominantly Mediterranean and arid, with a rare rainfall (100-200 mm per year), concentrated mainly in winter and autumn. However, over the last 20 years, the GuelmimOued Noun region has experienced a disruption of seasonal rainfall and a clear warming trend of around $0.7{ }^{\circ} \mathrm{C}$ [6]. The rainfall recorded during the 2014-2015 hydrological year generated significant floods and runoffs, both in terms of volume and maximum flow. On the other hand, the hydrological year 2015-2016 was dry with a temperate winter and without continental input for the Aglou-Sidi Ifni coastline. This work was carried out during the autumn and winter seasons of these two cycles and focuses on the study of the impact of these changes on the phytoplankton community of this coastline.

\section{Materials and methods}

\subsection{Sampling}

The water samples used for the quantitative study of phytoplankton and for the determination of nutrient salts were taken, using a two-litre Niskin bottle, one metre from the surface. While the phytoplankton samples for the qualitative phytoplankton study was collected using plankton net. These samplings were carried out during the autumn and winter periods of two annual cycles (April 2014-March 2016). Three stations of the AglouSidi Ifni coastline (Fig. 1) were surveyed regularly during this period with a bi-monthly

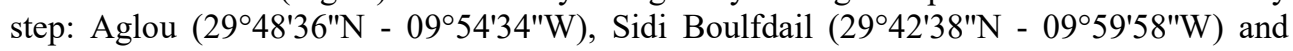
Sidi Ifni $\left(29^{\circ} 23^{\prime} 19^{\prime \prime} \mathrm{N}-10^{\circ} 11^{\prime} 53^{\prime \prime} \mathrm{W}\right)$, the positions of these stations were validated by Global Position System (GPS).

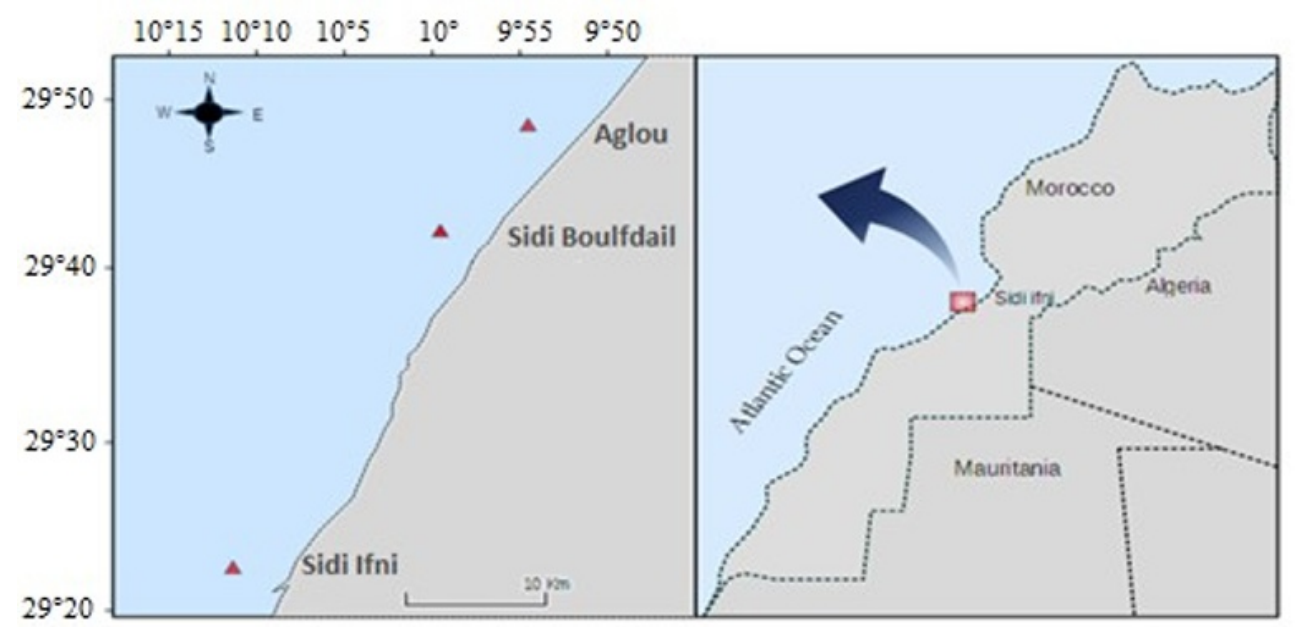

Fig. 1. Map of sampling stations. 


\subsection{Physicochemical parameters}

\subsubsection{In situ measurements}

Water temperature, salinity and dissolved oxygen were measured in situ at the surface using a multi-parameter instrument (WTW Multiline P4). Transparency was measured in metres using an immersed Secchi disc at each station.

\subsubsection{Analyses carried out in laboratory}

The elements analysed in laboratory are: nitrites $\left(\mathrm{N}^{-\mathrm{NO}_{2}}{ }^{-}\right)$, nitrates $\left(\mathrm{N}-\mathrm{NO}_{3}{ }^{-}\right)$, ammoniacal nitrogen $\left(\mathrm{N}-\mathrm{NH}_{4}{ }^{+}\right)$and orthophosphate ions $\left(\mathrm{P}_{-} \mathrm{PO}_{4}{ }^{3-}\right)$. These analyses were performed using an absorption spectrophotometer according to the nutrient analysis protocol described in the Manual of Marine Chemical Analysis [7]. Chlorophyll "a" was determined by measuring the absorbance of the extract with a spectrophotometer at wavelengths of 665 $\mathrm{nm}$ and $750 \mathrm{~nm}$ before and after acidification by the monochromatic method [8].

\subsection{Phytoplankton}

Biological samples are immediately fixed with Lugol and preserved with $5 \%$ formaldehyde. In the laboratory, the determination and enumeration of phytoplankton is carried out according to the Utermöhl method [9]. Individuals of each species are counted in $10 \mathrm{ml}$ sedimentation tanks, under an inverted microscope of the ULWCD 0.30 OLYMPUS type (G: 100; 400), after the sample has been decanted for at least $6 \mathrm{~h} \mathrm{[10],}$ according to a method inspired by Hasel and described by Sournia [11]. The specific identification of phytoplankton is based on visual observation of the general characteristics and remarkable morphological attributes of the cells and using appropriate identification keys [12-17]. The final result of the count in the sedimentation chamber is converted to a concentration in number of cells per litre (Cell/1).

\subsection{Statistical treatment}

In order to determine the impact of floods and droughts as well as the morphology of the coast on the spatial and temporal variability of phytoplankton, a PCA (Principal Component Analysis) was carried out, using the R software [18], from the data matrix of this study. The variables considered in this statistical study are the above-mentioned physicochemical parameters, the concentration of chlorophyll "a" and cell densities of total phytoplankton and its two main groups (diatoms and dinoflagellates) in samples collected at the three stations during the winter and fall seasons of the two annual cycles of this study.

\section{Results}

\subsection{Physicochemical parameters}

The evolution of the water temperature is almost the same in the three stations with high values during the autumn periods and low values during the winter periods. The minimum temperature values were recorded on February 2015 with $16.4{ }^{\circ} \mathrm{C}$ at Aglou, $16.1{ }^{\circ} \mathrm{C}$ at Sidi Boulfdail and $16^{\circ} \mathrm{C}$ at Sidi Ifni. The maximum values were recorded on October 2015 with $21.8^{\circ} \mathrm{C}, 21.5^{\circ} \mathrm{C}$ and $21{ }^{\circ} \mathrm{C}$ respectively. The Sidi Ifni station is cooler than the other two 
stations (Fig. 2). The values recorded during the drought period (A15-W16) are higher than those recorded during the flood period (A14-W15).

The analysis of variance revealed a very highly significant difference $(p<0.001)$ between the seasonal averages of water temperature at each of the three stations along the Aglou-Sidi Ifni coastline. In addition, Tukey's test of multiple comparisons of these averages disclosed a spatiotemporal heterogeneity in the temperature of the coastal waters of Aglou-Sidi Ifni coastline.

The low salinity values of the waters of the Aglou Sidi Ifni coast were recorded on December 2015 (35.45 g/l in Aglou, $35.47 \mathrm{~g} / 1$ in Sidi Boulfdail and $35.44 \mathrm{~g} / 1$ in Sidi Ifni) and the maximum values were recorded in November 2015 in the Sidi Boulfdail station (35.65 g/l) and on October 2015 in the Aglou (35.65 g/l) and Sidi Ifni (35.62 g/l) stations. The salinities recorded during the drought period seasons are higher than those recorded during the same seasons of the flood period (Fig. 2).

The analysis of variance revealed a very highly significant difference $(p<0.001)$ between the seasonal averages of salinity recorded in the three stations of the Aglou-Sidi Ifni coast.

The evolution of dissolved oxygen concentration is similar at the three stations of the Aglou-Sidi Ifni coast with concentrations greater than or equal to $8 \mathrm{mg} / \mathrm{l}$ in winter 2015 and concentrations less than $8 \mathrm{mg} / \mathrm{l}$ and greater than $6.5 \mathrm{mg} / \mathrm{l}$ during the other periods of this study. The dissolved oxygen concentrations recorded during the seasons of flood period are higher than those recorded during the same seasons of the drought period (Fig. 2).

Analysis of the variance of dissolved oxygen in the waters of the Aglou-Sidi Ifni coastline divulged a very highly significant seasonal variability $(p<0.001)$ of this parameter at the three stations of this coastline.

The maximum transparency $(14.5 \mathrm{~m})$ was recorded at the Aglou and Sidi Boulfdail stations in winter 2016 and the minimum transparency $(6 \mathrm{~m})$ was recorded at the Sidi Ifni station in autumn 2014.

The highest seasonal averages of water transparency were recorded in winter 2016 and the lowest in autumn 2014 (Fig. 2). The analysis of variance divulged a highly significant difference between the seasonal averages of transparency in the Sidi Ifni station $(p<0.01)$. However, this difference is non-significant in the Aglou and Sidi Boulfdail stations ( $p>$ $0.05)$.
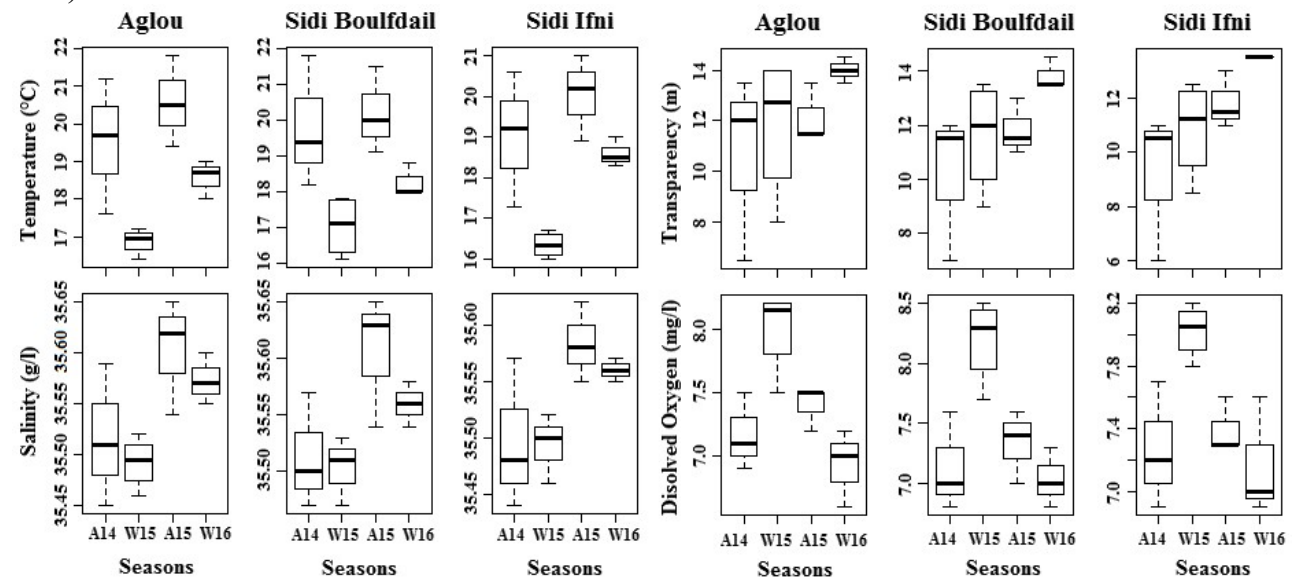

Fig. 2. Seasonal and inter-annual variability of the temperature, salinity, disolved oxygen and transparency in the three stations of the Aglou-Sidi Ifni coastline. The seasons are represented by their initials (A: autumn, W: winter) followed by two digits that indicat the year. 
High nutrient concentrations were recorded in winter 2015 with $391 \mu \mathrm{g} / 1 \mathrm{~N}-\mathrm{NO}_{3}{ }^{-}, 36.34 \mu \mathrm{g} / 1$ $\mathrm{N}_{-} \mathrm{NO}_{2}{ }^{-}, 10.26 \mu \mathrm{g} / \mathrm{l} \mathrm{N}-\mathrm{NH}_{4}{ }^{+}$and $152 \mu \mathrm{g} / \mathrm{l} \mathrm{P}-\mathrm{PO}_{4}{ }^{3-}$. While the lowest concentrations were recorded in winter 2016 with $186 \mu \mathrm{g} / 1,19.32 \mu \mathrm{g} / \mathrm{l}, 5.4 \mu \mathrm{g} / \mathrm{l}$ and $35.15 \mu \mathrm{g} / \mathrm{l}$ respectively (Fig. 3 ) .

Analysis of variance revealed a very highly significant difference $(\mathrm{p}<0.001)$ between the seasonal averages of $\mathrm{N}_{-} \mathrm{NO}_{2}{ }^{-}$and $\mathrm{N}_{-} \mathrm{NH}_{4}{ }^{+}$concentrations recorded in the three stations. A highly significant difference $(\mathrm{p}<0.01)$ was found between the seasonal means of $\mathrm{N}_{-} \mathrm{NO}_{3}{ }^{-}$ concentrations in each station. While the difference between the seasonal averages for P$\mathrm{PO}_{4}{ }^{3-}$ was significant $(\mathrm{p}<0.05)$ in Aglou station and non-significant $(\mathrm{p}>0.05)$ at the other two stations.
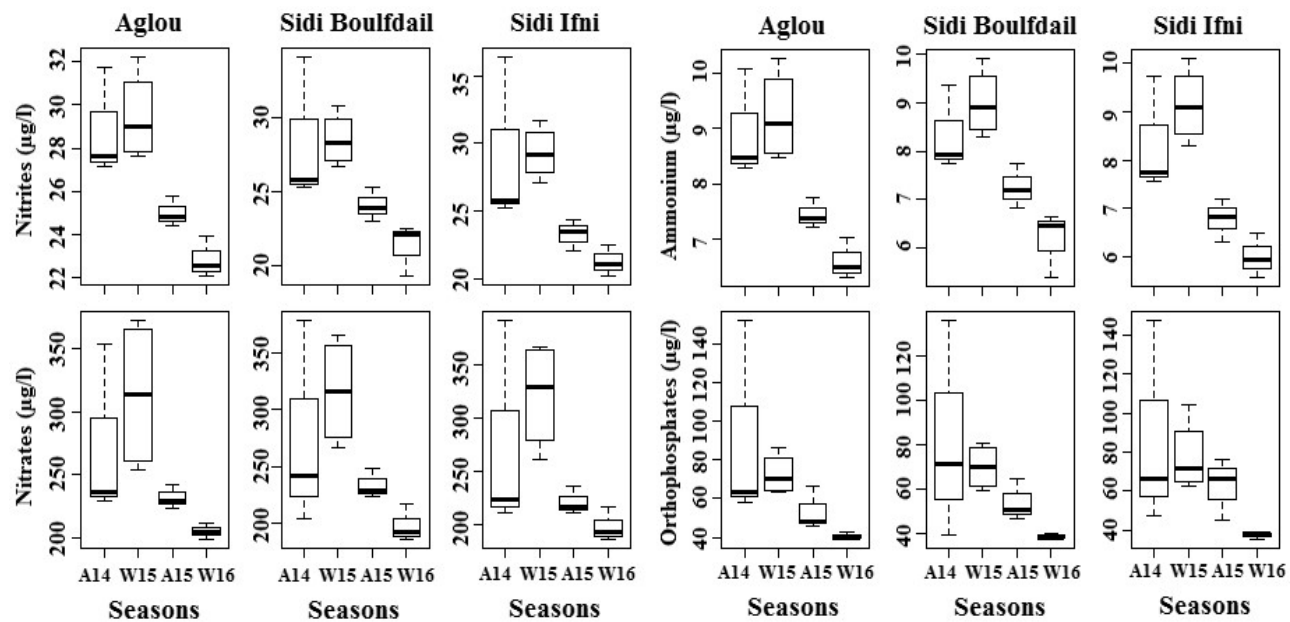

Fig. 3. Seasonal and inter-annual variability of the nitrates, nitrites, ammonium and orthophospates in the three stations of the Aglou-Sidi Ifni coastline. The seasons are represented by their initials (A: autumn, W: winter) followed by two digits that indicat the year.

\subsection{Phytoplankton}

\subsubsection{Specific Richness (SR) and Chlorophyll "a"}

This study disclosed significant phytoplankton diversity (233 taxa) within the Aglou-Sidi Ifni coastline. The number of taxa recorded in the Aglou-Sidi Ifni coastline is higher than that recorded in the majority of sites on the Moroccan Atlantic coast [19, 20].

Diatoms and dinoflagellates are the main phytoplankton groups in this ecosystem. These two groups represent respectively $54 \%$ and $42 \%$ of the phytoplankton species richness in this zone.

Seasonal averages of phytoplankton specific richness recorded during the drought period (A15-W16) exceed those recorded during the flood period (A14-W15) (Fig. 4).

The maximum seasonal averages for SR of phytoplankton were recorded in winter 2016 with $54 \pm 2.08$ species in the Aglou station, $49 \pm 2.08$ species in the Sidi Boulfdail station and $50 \pm 2.65$ species in the Sidi Ifni station.

The analysis of variance revealed a significant difference $(\mathrm{p}<0.05)$ between the seasonal means of the diatoms and dinoflagellates species richness at the three stations. This analysis did not reveal significant differences $(p>0.05)$ between seasonal averages of total phytoplankton species richness.

The average chlorophyll "a" concentrations recorded at the three stations during the dry period seasons (A15-W16) are higher than those recorded at these stations during the same 
flood period seasons (A14-W15). Maximum concentrations were recorded in the autumn of 2015 and minimum concentrations in the winter of 2015 (Fig. 4).

The maximum seasonal means for chlorophyll "a" were recorded in autumn 2015 with $0.90 \pm 0.06 \mu \mathrm{g} / \mathrm{l}$ in Aglou, $0.91 \pm 0.06 \mu \mathrm{g} / \mathrm{l}$ in Sidi Boulfdail and $0.87 \pm 0.05 \mu \mathrm{g} / \mathrm{l}$ in Sidi Ifni. While the minimum seasonal averages were recorded in winter 2015 in Aglou and Sidi Boufdail stations with $0.72 \pm 0.14 \mu \mathrm{g} / \mathrm{l}$ and $0.73 \pm 0.11 \mu \mathrm{g} / \mathrm{l}$ respectively and in autumn 2014 in the Sidi Ifni station with $0.70 \pm 0.09 \mu \mathrm{g} / \mathrm{l}$.

The analysis of variance did not reveal any significant difference $(p>0.05)$ between the seasonal means of chlorophyll "a" concentration in the three stations.

Aglou
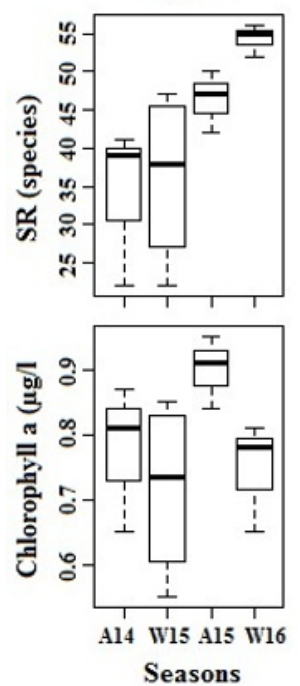

Sidi Boulfdail
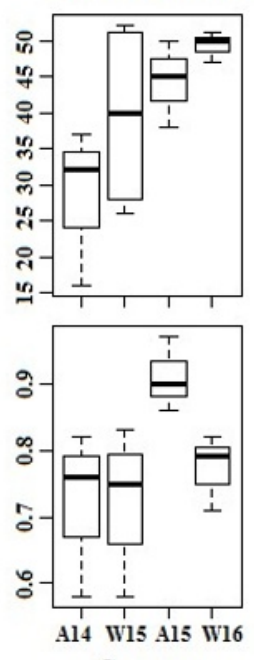

Seasons
Sidi Ifni
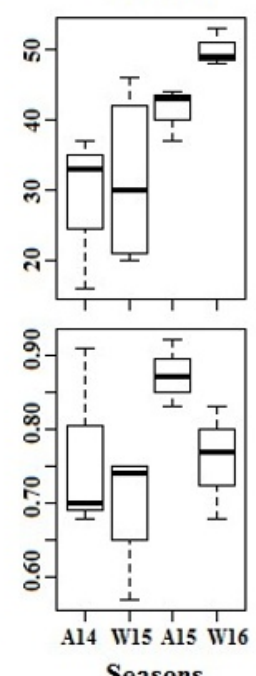

Seasons

Fig. 4. Seasonal and interannual variability of the species richness (SR) and chlorophyll "a" in the three stations of the Aglou-Sidi Ifni coastline. The seasons are represented by their initials (A: autumn, W: winter) followed by two numbers indicating the year .

\subsubsection{Relative abundance of different phytoplankton groups}

The seasonal averages of total phytoplankton abundance recorded during the flood period $\left(8.10^{3}\right.$ cell/1 to $12.10^{3}$ cell/l) are lower than those recorded during the drought period $\left(32.10^{3}\right.$ cell/1 to $52.10^{3}$ cell/1).

Analysis of variance divulged a difference between seasonal averages of phytoplankton abundances in each of the three stations. This difference is very highly significant in the Aglou $\left(\mathrm{F}=9.97, \mathrm{p}=1.84 .10^{-5}\right)$ and Sidi Ifni $(\mathrm{F}=5.028, \mathrm{p}=0.00067)$ stations and highly significant in the Sidi Boulfdail station $(\mathrm{F}=5.909, \mathrm{p}=0.00181)$.

The relative abundance of diatoms is higher during the fall and winter seasons of the flood year and exceeds that of the other phytoplankton groups. While the relative abundance of dinoflagellates is greatest during the fall and winter seasons of the drought year and exceeds that of other phytoplankton groups (Fig. 5).

The difference between the seasonal averages of relative diatom abundance is highly significant $(\mathrm{p}<0.01)$ in the Aglou and Sidi Boulfdail stations and significant $(\mathrm{p}<0.05)$ in the Sid Ifni station, while the difference between the seasonal means of the relative abundance of dinoflagellates is very highly significant $(p<0.001)$ in the Sidi Boulfdail station, highly significant $(\mathrm{p}<0.01)$ in the Aglou station and significant $(\mathrm{p}<0.05)$ in the Sidi Ifni station. 


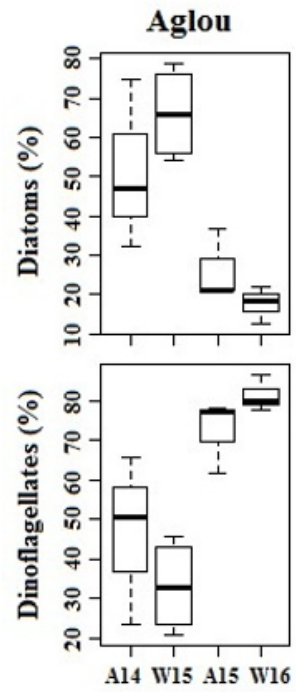

Seasons
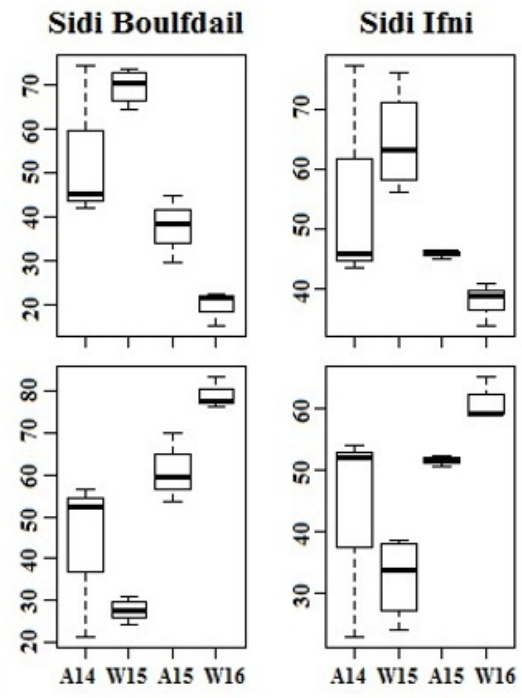

Seasons

Seasons

Fig. 5. Seasonal and inter-annual variation of the relative abundance of diatoms and dinoflagellates in the three stations of Aglou-Sidi Ifni littoral. The seasons are represented by their initials (A: autumn, $\mathrm{W}$ : winter) followed by two digits that indicate the year.

\subsection{Physicochemical and phytoplankton typology of the Aglou-Sidi Ifni coastline}

In order to visualize the relationship between climate change and the physicochemical and phytoplankton typology of the Aglou-Sidi Ifni coastline, a standardized PCA was carried of a data matrix containing the measurements of the above-mentioned environmental variables, the concentration of chlorophyll "a", the abundance of the main phytoplankton groups (diatoms and dinoflagellates) and the abundance and specific richness of the total phytoplankton.

The factorial design F1*F2 represents a total inertia of $78.23 \%$ (Fig. 6). Salinity, water transparency, dinoflagellates density and phytoplankton species richness are positively correlated with each other and with the F1 axis. Nutrient salt concentration and diatom abundance are positively correlated with each other and negatively correlated with the F1 axis (Fig. 6).

Total phytoplankton density and temperature contribute strongly to the formation of the factorial axis F2 and are positively correlated with each other and with this axis. Water transparency and phytoplankton species richness are negatively correlated with the second factorial axis (Fig. 6).

The concentration of chlorophyll "a" is positively correlated with the two factorial axes and thus contributes to the formation of the two factorial axes of this PCA (Fig. 6). 


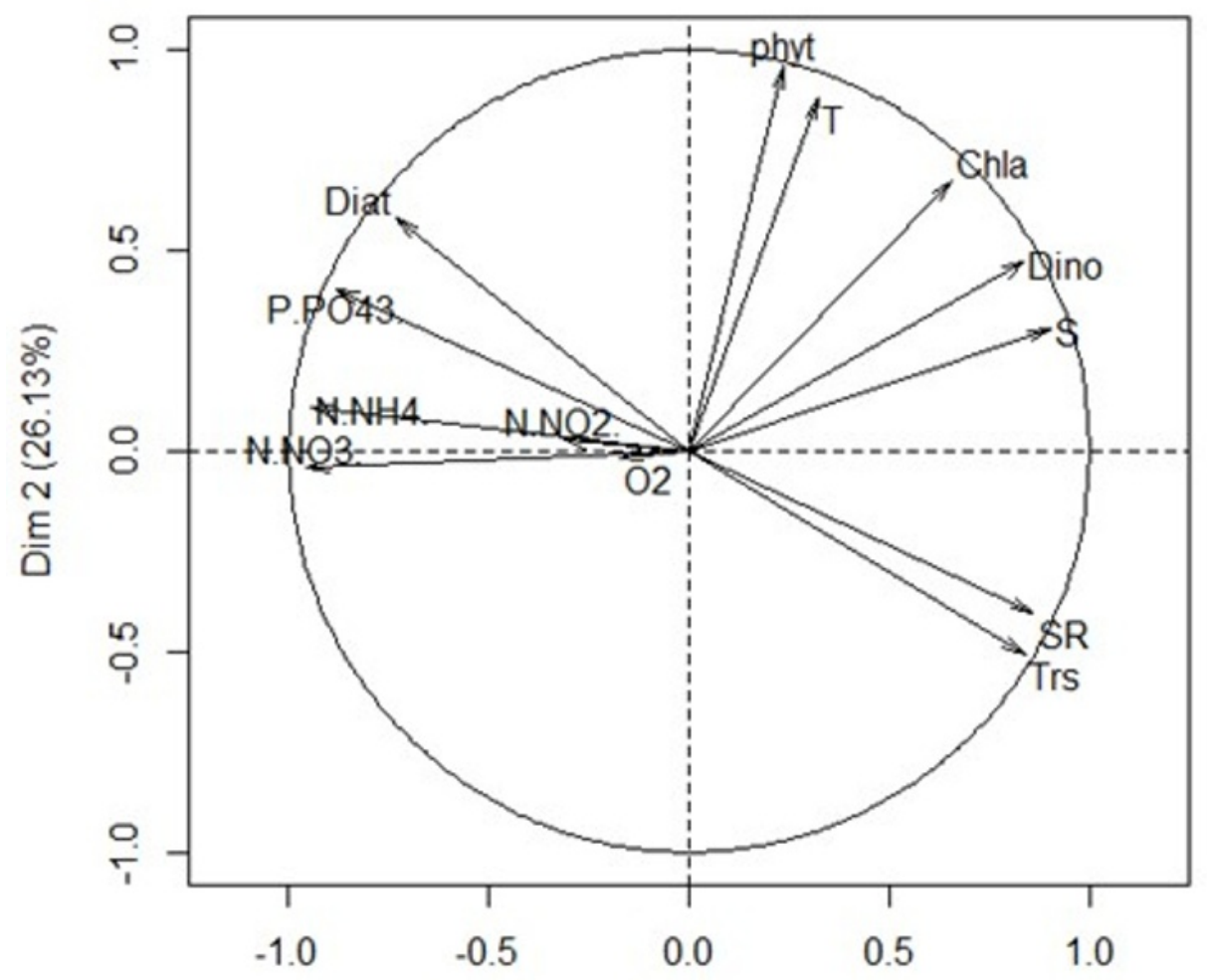

$\operatorname{Dim} 1(52.10 \%)$

Fig. 6. Variables factor map (PCA): Temperature (T), Salinity (S), Dissolved oxygen $\left(\mathrm{O}_{2}\right)$,

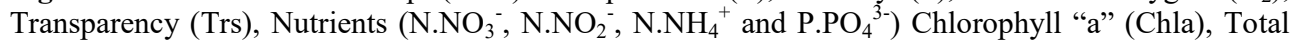
phytoplankton abundance (Phyt), Diatom abundance (Diat), Dinoflagellate abundance (Dino) and Phytoplankton species richness (SR).

The projection of the individuals (Stations-Seasons) on the factorial plane F1*F2 and the hierarchical classification allowed to highlight a spatiotemporal variability of the characteristics (physicochemical and phytoplankton) of the waters of the Aglou-Sidi Ifni coastline and a clear difference between the two periods of this study (Fig. 7).

The first grouping is formed by the samples taken at the three stations during the flood period (autumn 2014 and winter 2015). These samples are characterized by high nutrient contents, a relative abundance of diatoms higher than that of dinoflagellates, minimal temperatures and transparencies (Fig. 7).

The second grouping groups the samples collected at the three stations during the drought period (fall 2015 and winter 2016). These samples are characterized by a relative abundance of dinoflagellates that exceeds that of diatoms, high temperatures and clearances, and low nutrient concentrations. Chlorophyll "a" concentrations in the samples from this grouping are higher than those recorded in the samples from the first grouping.

Each of the two groups is made up of two subgroups, each of which represents the samples collected at the three stations during one season (flood or drought period). For each season, the samples taken in the Sidi Ifni station differ from those taken at the other two stations on the Aglou-Sidi Ifni coast (Fig. 7). 


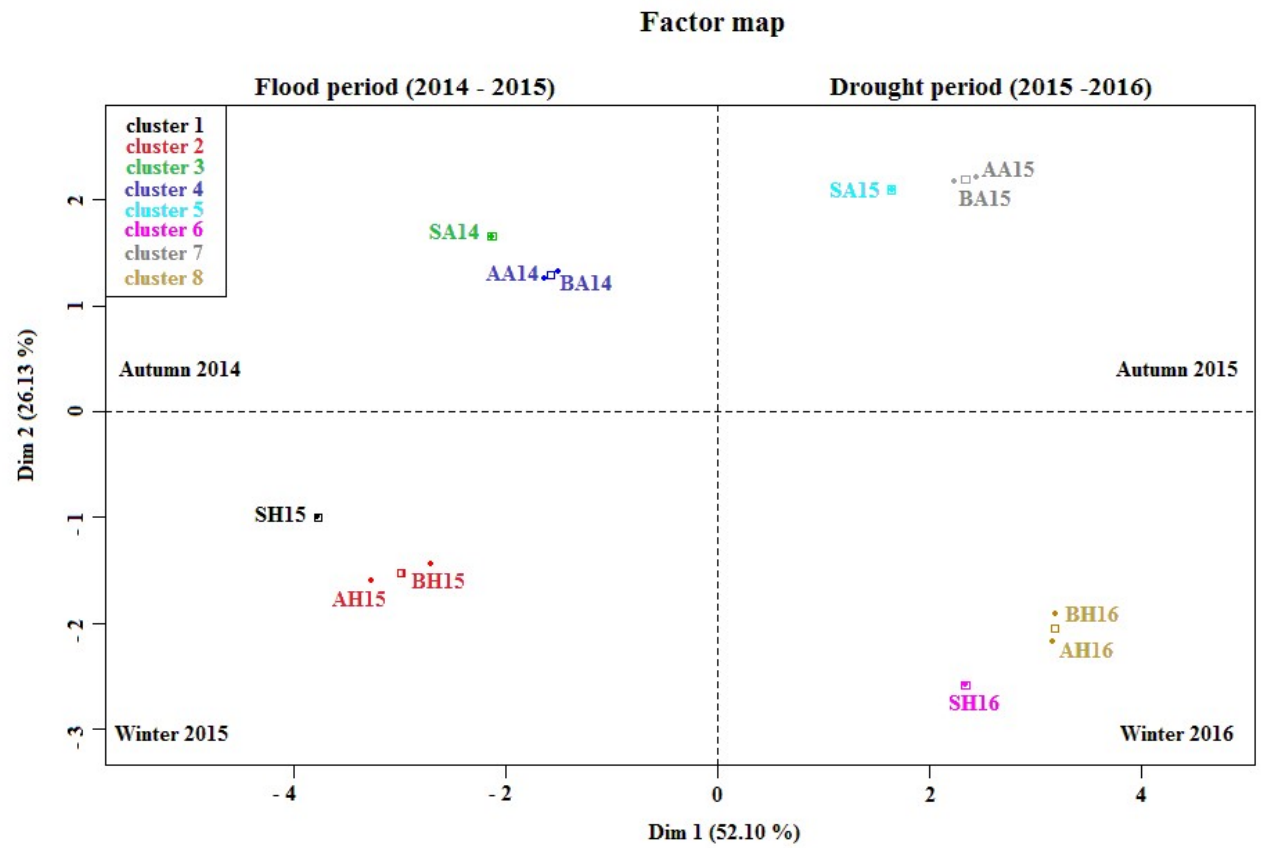

Fig. 7. Individuals projection on the factorial plane $\left(\mathrm{F}_{1} * \mathrm{~F}_{2}\right)$. Each individual is represented by the initial of the station (A: Aglou, B: Sidi Boulfdail and S: Sidi Ifni) followed by the initial of the season (A: autumn, W: winter) and by two digits that represent the year.

\section{Discussion}

\subsection{Physicochemical characteristics of waters}

The work carried out in the temperate and subtropical zones of the North Atlantic showed that the normal dynamics of water masses are naturally regulated by the alternation of the agitated and cold winter season, and the less agitated and hot summer season [21]. In Morocco, there are typically two rainy periods per year, one in autumn and the other in winter. The number of rainy days varies from 30 in the south of the country to approximately 70 in the north [22]. In the Guelmim-Oued Noun region, this rhythm seems to be modified by the hydro-meteorological and climatic hazards that this region has been undergoing over the last 20 years. In fact, precipitation in this region has shown great spatial and temporal variability [23]. The provinces of Guelmim and Sidi Ifni experienced bad weather conditions during the first period of this study (autumn 2014-winter 2015). These conditions generated high floods and strong agitation of the waters of the Aglou-Sidi Ifni coastline during this period. This led to a decrease in temperature, salinity and transparency and an increase in the concentration of dissolved oxygen and nutrient salts. The second period (autumn 2015-winter 2016) was on the contrary drier (no continental input) and the waters of this coastline were less agitated, warmer, more saline, more transparent, less oxygenated and less rich in nutrients.

The lowest seasonal temperature averages were recorded during the first period of this study and the highest during the second period. This warming was also reported in a preliminary study comparing the spring periods of two successive annual cycles (20132014) [24]. In the North Atlantic Ocean, the most pronounced warming since the 1960s has been recorded in the temperate and subtropical coastal zones [3]. The warming of water that 
accompanies the lack of continental water supply has a range of effects, both direct and indirect, on the physicochemical and biochemical processes occurring within the water body, as well as on aquatic biocenoses [25].

\subsection{Phytoplankton Communities}

Phytoplankton biomass is generally estimated by the concentration of chlorophyll a (Chla), which provides a simple and integrative measure of the response of the phytoplankton community to nutrient enrichment [26].

The seasonal mean chlorophyll "a" concentration varies between $0.70 \pm 0.09 \mu \mathrm{g} / \mathrm{l}$ recorded at the Sidi Ifni station in autumn 2014, and $0.91 \pm 0.06 \mu \mathrm{g} / \mathrm{l}$ recorded at the Sidi Boulfdail station in autumn 2015. The averages recorded during the drought period are higher than those recorded during the flood period. Seasonal averages of chlorophyll "a" concentration recorded in each of the three stations did not differ significantly from each other. This would be explained by the fact that environmental conditions are unfavourable for the photosynthetic activity of phytoplankton during the flood and dry periods of this study. In the eastern channel and southern bay of the North Sea, low chlorophyll "a" concentrations are recorded during the season of low light intensity and high chlorophyll "a" concentrations are recorded when light intensity increases [27].

The phytoplankton species richness recorded in the Aglou-Sidi Ifni coastline (233 taxa) is higher than that recorded at most sites on the Moroccan Atlantic coast [28-30]. Diatoms and dinoflagellates represent $54 \%$ and $42 \%$ of this species richness respectively. These two groups are the most abundant. The dominance of these two phytoplankton groups has also been reported in other ecosystems around the world [1, 31, 32].

The seasonal averages of total phytoplankton abundance recorded during the flood period $\left(8.10^{3}\right.$ cell/1 to $12.10^{3}$ cell/l) are lower than those recorded during the drought period $\left(32.10^{3}\right.$ cell/1 to $52.10^{3}$ cell/1). In the channel of Oualidia Lagoon the low phytoplankton cell concentrations $\left(1.64 .10^{3}\right.$ cell/1 to $12.24 .10^{3}$ cell/l) are recorded during the cool period and the maximum concentration $\left(1.19 .10^{5}\right.$ cell/l) is recorded during the autumn of the dry period [28]. The total phytoplankton abundance recorded in winter $2002\left(2.10^{3}\right.$ cell/l) in the Bay of Agadir [29] remains lower than those recorded in Aglou-Sidi Ifni coastline during the two winter seasons of this study $\left(8.10^{3}\right.$ cell/1 during winter 2015 and $32.10^{3}$ cell/1 during winter 2016).

It should be noted that the increase in temperature and the decrease in nutrient concentration during the drought period may be one of the factors that favour the increase in the species richness and relative abundance of dinoflagellates and the decrease in those of diatoms in the Aglou-Sidi Ifni coastline during the drought period. The same phenomenon has been reported in different studies carried out on the Moroccan Atlantic coast [30] and the Mediterranean [33].

\section{Conclusion}

The climatic forcing that the province of Sidi Ifni underwent during the study period led to temporal modifications of the physicochemical characteristics of the waters of the AglouSidi Ifni coastline (temperature, salinity, transparency, concentration of dissolved oxygen and nutritive salts) which would be at the origin of the temporal variability of the phytoplankton typology of this coastline. During floods and heavy swells, the water is more turbulent, more oxygenated, cooler, richer in nutrients and less transparent. This change is thought to be responsible for the decrease in species richness and relative abundance of dinoflagellates and the increase in those of diatoms. On the other hand, the period of severe drought and the weak swells is characterized by a stability of the water column with an 
increase in temperature, transparency and a decrease in the concentration of dissolved oxygen and nutrients, which may be the cause of the increase in the specific richness and relative abundance of dinoflagellates and the decrease in those of diatoms.

This study also disclosed a spatial variability in the typology of phytoplankton which would be linked to the spatial variation in the intensity of the currents (canary current and updraft) under the effect of the morphology of the coast in this zone which curves towards the west and carries Cape Aglou at its northern end, which makes the station of Sidi Ifni more exposed to these currents compared to the other two stations which are less exposed.

\section{References}

1. P. Bougis, Ecologie du plancton marin: Le phytoplancton I (Masson et scie, Editeurs, Paris, 1974)

2. S. Gobert, P. Lejeune, J. Romano, Température de l'Eau de Mer, in: Changement climatique et milieu marin en Corse (Report Card IUCN, 2018)

3. G. Beaugrand, E. Goberville, VertigO 8, 14 (2010)

4. J.E. Cloern, Aquatic ecology 33, (1999)

5. C. Sauvage, Ann. Phys. Globe Météo. Inst. Sci. Chérif 20, (1963)

6. J. Alibou, Impacts of climate change on water resources and wetlands in Morocco, in Mediterranean Regional Round Table, 10-11 December 2002, Athens, Greece (2002)

7. A. Aminot, M. Chaussepied, Manuel des analyses chimiques en milieu marin (Centre national pour l'exploitation des océans, Paris, 1983)

8. C.J. Lorenzen, Limnol Oceanogr 12, 343-346 (1967)

9. H. Utermöhl, Arch. Hydrobiol 9,1-38 (1958)

10. F. M. Reid, J. Plankton. Res 5, 235-252 (1983)

11. A. Sournia, Form and function in marine phytoplankton, Biol Rev 57, 347-394 (1982).

12. A. Sournia, Atlas du phytoplancton marine: Cyanophcées dictyochophycées dinophycées raphidophycées (Editions du CNRS, France, 1986).

13. E. Balech, Helgol Mar Res 44, 387 (1990)

14. E. Nézan, G. Piclet, H. Grossel, Guide pratique à l'usage des analystes du réseau national de surveillance phytoplancton (Ifremer, 1996)

15. G.R. Hasle, E.E. Syvertsen, K.A. Steidinger, K. Tangen, C.R. Tomas, Identifying marine diatoms and dinoflagellates (Elsevier, 1996)

16. G. Paulmier, DRV-RH-RST 14, 428 (1997)

17. L. Bérard-Therriault, M. Poulin, L. Bossé, Guide d'identification du phytoplancton marin de l'estuaire et du golfe du Saint-Laurent: incluant également certains protozoaires (NRC Research Press, 1999)

18. R.C. Team, R: A language and environment for statistical computing (Vienna, Austria, 2013)

19. M. Fraikech, A. Berraho, M. Ramdani, A. Chafik, M. Serghini, A. Moukrim, Mar. Life 15, 9 (2005)

20. L. Natij, Z. Damsiri, K. Khalil, M. Loudiki, O. Ettahiri, K. Elkalay, Int. J. Adv. Res 2, 1022-1032 (2014)

21. S. Gobert, Le Plancton, in: Changement climatique en Corse (Report Card IUCN, 2018) 
22. NU, Examen des performances environnementales-Maroc, in: Série des examens des performances environnementales (Comission economique des nations unies pour l'europebureau pour l'afrique du nord, New york et Genève, 2014)

23. F. Elame, R. Doukkali, Revue Marocaine des Sciences Agronomiques et Vétérinaires 6, 124-131 (2018)

24. E.M. Gallouli, J. Aziko, H. Oulad Ali, M. El hafa, A. Aamiri, IJPSAT 4, 7 (2016)

25. P. Balland, La sécheresse: conséquences sur le milieu, salubrité, environnement, La Houille Blanche 2, 103-117 (1990)

26. J. Brodie, G. De'Ath, M. Devlin, M. Furnas, M. Wright, Mar Freshw Res 58, 342-353 (2007)

27. A. Lefebvre, W. Perrouchet, Résultats de la mise en oeuvre des réseaux REPHY et SRNZones côtières de la Manche orientale et de la baie sud de la Mer du Nord-Bilan de l'année 2015 (RST.LER.BL, 2016)

28. A. Bennouna, O. Assobhei, B. Berland, J. El Attar, Mar. Life 10, 3-18 (2000)

29. M. Fraikech, Variabilité spatio-temporelle des populations phytoplanctoniques dans la baie d'Agadir-Maroc (Faculté des sciences, Univ Ibn Zohr, Agadir, 2008)

30. A. Loumghari, R. Akallal, A. Mouradi, A. Mouradi, Afrique science 5, 128-148 (2009)

31. L. Somoue, Structure des communautés planctoniques de l'écosystème pélagique de l'Atlantique sud marocain entre Cap Boujdor et Cap Blanc $\left(26^{\circ} 30^{\prime}-21^{\circ} \mathrm{N}\right)$ (Fac Sc Ain chock,Univ Hassan II, Casablanca, 2004)

32. L. Lampert, Dynamique saisonnière et variabilité pigmentaire des populations phytoplanctoniques dans l'Atlantique Nord (Golfe de Gascogne) (Iuem, Univ Bretagne Occidentale, 2001)

33. M. Kamel, Etude de surveillance du phytoplancton nuisible sur la méditerranée marocaine dans la région de Tétouan (Restinga-kaâ sras) (IAV Hassan II, Rabat, 1997) 